\title{
ДИПЛОМАТИЧНІ ПРЕДСТАВНИЦТВА УНР - ОРГАНІЗАТОРИ ГРОМАДСЬКОГО ЖИТТЯ УКРАЇНСЬКОЇ ПОЛІТИЧНОЇ ЕМІГРАЦІЇ У БАЛКАНСЬКИХ КРАЇНАХ
}

\author{
В. М. Власенко
}

\begin{abstract}
Власенко В. М. Дипломатичні представництва УНР - організатори громадського життя української політичної еміграції у Балканських країнах. У статті на основі раніше невідомих архівних документів розглядається питання про роль дипломатичних представництв УНР у балканських країнах у громадському житті української еміграції. Основна увага приділяється діяльності посольств і місій зі створення громадських організацій. Розповідається про заходи Надзвичайної дипломатичної місії УНР у Румунії щодо формування мережі громадських організацій, заходи дипломатичних установ УНР у Болгарії та Королівстві сербів, хорватів і словенців щодо надання допомоги емігрантам. Робиться висновок про те, що найбільш активно у справі створення емігрантських громадських організацій діяла Дипломатична місія УНР у Румунії, найменш активно - Генеральне консульство УНР у КСХС. Це залежало від низки факторів - ставлення влади країн-реципієнтів до української еміграції, ступеня самоорганізації еміграції та діяльності українських дипломатів.

Ключові слова: Болгарія; Королівство сербів, хорватів і словенців; посольство; Надзвичайна дипломатична місія; Румунія; українська еміграція; Українська Народна Республіка.
\end{abstract}

Власенко В. Н. Дипломатические представительства УНР - организаторы общественной жизни украинской политической эмиграции в Балканских странах. В статье на основе ранее неизвестных архивных документов рассматривается вопрос о роли дипломатических представительств УНР в балканских странах в общественной жизни украинской эмиграции. Основное внимание уделяется деятельности посольств и миссий по созданию общественных организаций. Рассказывается о мерах Чрезвычайной дипломатической миссии УНР в Румынии по формированию сети организаций, мерах посольств УНР в Болгарии и Королевстве сербов, хорватов и словенцев по оказанию помощи эмигрантам. Делается вывод о том, что наиболее активно в деле создания эмигрантских общественных организаций действовала Дипломатическая миссия УНР в Румынии, наименее активно - Генеральное консульство УНР в КСХС. Это зависело от ряда факторов - отношения власти стран-реципиентов к украинской эмиграции, степени самоорганизации самой эмиграции и действий украинских дипломатов.

Ключевые слова: Болгария; Королевство сербов, хорватов и словенцев; посольство; Чрезвычайная дипломатическая миссия; Румыния; украинская эмиграция; Украинская Народная Республика.

Vlasenko V. M. The Diplomatic Missions of UPR - the Organizers of Social Life of Ukrainian Emigration in the Balkan Countries. The article is based of previously unknown archive records related to the role of the UPR diplomatic missions in social life of the Ukrainian emigration in Balkans. The study has its main focus on embassies' and diplomatic missions' work in the field of civic society organizations formation. It covers practices of the Extraordinary Diplomatic Mission of UPR in Romania concerning the establishment of chain civil society organizations. The article also examines the practices related to rendering of assistance to refugees by the Embassies of the UPR in Bulgaria and the Kingdom of Serbs, Croats and Slovenes. The author concludes that the Diplomatic Mission of the UPR in Romania was the most active in the establishment of the civic society organizations for refugees, whilst the Embassy of the UPR in the Kingdom of Serbs, Croats and Slovenes was the most passive one. The abovementioned arrangements varied depending on the number of factors such as the state concerns towards Ukrainian emigration, the level of refuge self-organization as well as efficacy of Ukrainian diplomats.

Keywords: Bulgaria; The Kingdom of Serbs, Croats and Slovenes; embassy; Extraordinary Diplomatic Mission; Romania; Ukrainian emigration; The Ukrainian People's Republic.

Перша світова війна та революційні події 1917-1921 pр. в Україні та Росії змусили декілька сотень тисяч українців залишити батьківщину. Еміграція з України здійснювалася двома напрямками: на захід - до Польщі, Чехословаччини і далі до Західної Європи, на південь - до балканських країн і Туреччини, а звідти - на Середземноморські острови та до Північної Африки. Еміграція на Балкани відбувалася трьома хвилями 1919-1920 рр. та двома потоками - через Дністер на румунську територію та морем із портів Криму і Пів- 
дня України. Специфікою південного напрямку еміграції було те, що до Болгарії, Греції, Королівства сербів, хорватів і словенців (КСХС) та Туреччини українці прибули у складі білих армій А. Денікіна та П. Врангеля, а до Румунії - у складі переважно військових частин Армії УНР та партизансько-повстанських загонів. Поряд із військовими Україну залишили й цивільні люди. Крім міжнародних благодійних організацій, Міжнародного Товариства Червоного Хреста, державних інституцій, церкви і громадських організацій країн-реципієнтів, першу допомогу українцям надавали і дипломатичні представництва УНР у цих країнах. Вони ж тією чи іншою мірою стали організаторами громадського життя української еміграції. Найбільші осередки еміграції у Південно-Східній Європі сформувалися в Болгарії, КСХС (з 1929 р. - Югославія) та Румунії. У нашій роботі ми розглядаємо не всю українську еміграцію, а лише політичну, тобто ту її частину, яка була політично вмотивованою, ідеологічно визначеною, організаційно структурованою та сповідувала ідею відновлення незалежної й суверенної української держави у різних її формах. Йдеться про тих емігрантів, які публічно визнали себе українцями, сповідували одну з поширених тоді ідеологій, крім комуністичної, належали до певного політичного середовища, були членами українських громадських організацій та виступали за розбудову суверенної та незалежної України.

У літературі 3 історії українських дипломатичних установ ${ }^{1}$ й української еміграції в Європі взагалі ${ }^{2}$, окремих іiі регіонах ${ }^{3}$, Болгарії ${ }^{4}, \mathrm{KCXC}^{5}$ i Румунії ${ }^{6}$ зокрема та діяльності керівника дипломатичних представництв УНР в Болгарії (1921) та Румунії (1919-1923) К. Мацієвича ${ }^{7} \epsilon$ згадки про надання українськими посольствами і місіями першої допомоги українським біженцям/емігрантам. Йдеться про допомогу продуктами харчування, ліками, грошима, сприяння рееміграції тощо. Проте поза увагою дослідників залишилися питання діяльності дипломатичних представництв у розбудові мережі емігрантських громадських організацій. Саме тому автор ставить собі за мету з'ясувати роль українських дипломатичних інституцій у створенні громадських організацій української еміграції в Болгарії, КСХС та Румунії.

Зауважимо, що питання про хвилі і потоки української еміграції до балканських країн $^{8}$, зміни іії кількісних показників ${ }^{9}$, соціальну структуру ${ }^{10}$, правове становище ${ }^{11}$, політичні середовища ${ }^{12}$ й окремі громадські організації еміграції ${ }^{13}$ вже знайшли висвітлення у науковій літературі.

Коли на початку 1920-х рр. українська еміграція усвідомила примарність сподівань на швидке повернення на батьківщину, постало питання пристосування до нових умов життя. Краще це було зробити спільними зусиллями, об'єднавшись у різноманітні громадські, кооперативні, культурно-освітні й інші організації. За їх допомогою можна було не лише покращити умови життя, збільшити свої матеріальні статки, але й забезпечити захист своїх прав та зберегти національну ідентичність. У кожній із країн регіону процес створення громадських організацій мав певну специфіку. Провідну роль в організації громадського життя емігрантів у цих країнах відігравали спочатку українські дипломатичні представництва.

У Румунії до створення українських громадських організацій громадську роботу серед емігрантів ініціювала, підтримувала та проводила Надзвичайна дипломатична місія (НДМ) УНР. У червні 1919 р. НДМ очолив професор Кость Мацієвич (1873-1942). Під його керівництвом у різний час працювали Іван Фещенко-Чопівський (1884-1952, радник), Лев Геркен, Михайло Любимський (секретарі), Федір Буткевич, Павло Мамчур (аташе), Олександр Кравець, Петро Коломак (урядовці), Лев Чопівський, Денис Маєр-Михальський (завідувач пресового бюро), а також службовці по вільному найму - отаман [на той час генерал-майор - B. B.] Віктор Зелінський (консультант із військових справ), Казимир Рафалович (водій), Адам Червінський (механік), Ілько Убович (вістовий) ${ }^{14}$. У лютому 1920 р. 3 реорганізованої Військової місії УНР при НДМ була створена військова секція у складі генерал-поручика Сергія Дельвіга (1866-1944, голова), полковника Демида Антончука (радник), хорунжих Василя (секретар) й Олександра Трепке, сотників Миколи Даньківа, Олександра Долинюка, Михальського та Якова Чайківського. До Місії належав і контр-адмірал Михайло Остроградський (1862-1923), який у квітні 1920 р. був призначений ще й уповноваженим Уряду УНР у справах військового та торговельного мореплавства на Півдні України ${ }^{15}$. 
Місія опікувалась інтернованими вояками Армії УНР. Регулярно надсилала до таборів українські часописи та книжки. Зусиллями НДМ і табірної культурно-освітньої управи були відкриті курси грамоти для неписьменних козаків, загальноосвітні курси з викладанням німецької, румунської та французької мов, учительський і літературний гуртки, «Спілка художників», створені український хор і культурна організація «Громада» у табоpi в м. Фегераш (рум. Făgăraş), почав виходити часопис «За тратами» ${ }^{16}$. Місія займалася пошуком роботи для інтернованих. Так, у червні 1921 р. на громадських роботах поблизу Бухареста працювала 131 особа, на цукровому заводі у Хотинському повіті - 100, на заводі у Джурджу (рум. Giurgiu) - 150 чоловік. За це козаки мали помешкання, харчування та щоденну платню у 10 леїв, фахівці - 20-30 леїв, а старшини-наглядачі - понад 50 леїв. Це давало їм можливість купити одяг і зробити невеликі заощадження. Згодом НДМ добилася того, щоб старшинам щомісяця видавали по одному комплекту одягу, два комплекти білизни і 300 леїв платні кожному. В таборі працювала споживча крамниця. У 1921 р. на Великдень НДМ виділила інтернованим 4 тис. леїв ${ }^{17}$.

Місія допомагала також й українцям Північної Буковини. Зокрема, грошова допомога і позики надавалися спортивному товариству «Довбуш» у Чернівцях. На прохання Чернівецької парафії НДМ організувала збір пожертв на купівлю дзвонів для греко-католицького храму ${ }^{18}$. Місія підтримувала матеріально і представників української культури. Так, упродовж кількох місяців письменниця Ольга Кобилянська (1863-1942) не отримувала пенсію від Міністерства освіти УНР. Тому НДМ виділила їй 2 тис. австрійських крон і 2 тис. російських (думських) рублів ${ }^{19}$. У першій половині 1921 р. вона двічі надала письменниці грошову допомогу (та в рахунок пенсії) на суму 550 австрійських крон і 1,3 тис. леїв, а згодом ще 3 тис. леїв пенсії за 1921 р. Українському художнику Євбезію Липецькому було замовлено портрети Богдана Хмельницького, Івана Мазепи й Тараса Шевченка по 2 тис. леїв кожний, художнику Миколі Івасюку (1865-1937) була надана грошова допомога в 1 тис. леїв для виїзду в Україну та на малювання картини «Богун веде козаків під Берестечко». Обидва художники виконали замовлення $\mathrm{HДМ}^{20}$.

Місія намагалася підтримувати український студентський рух у Румунії. Наприкінці листопада 1920 р. НДМ планувала заснувати 30 стипендій по 1,2 тис. леїв кожна для незаможних українських студентів у Бухаресті, Чернівцях та Яссах, надати матеріальну допомогу 5 студентським товариствам у тих самих містах по 5 тис. леїв кожному. Передбачалося також фінансово допомогти культурним товариствам і видавництвам, придбати підручники для українських шкіл, започаткувати публічні лекції та вистави ${ }^{21}$. Проте через нестачу коштів ці заходи були реалізовані лише частково. У березні 1921 р. НДМ сприяла створенню у Бухаресті українських студентських товариств і надала матеріальну допомогу кільком студентам ${ }^{22}$.

Місія започаткувала у Чернівцях видання тижневика «Народний голос». 22 квітня 1921 р. у цій справі К. Мацієвич зустрівся з міністром внутрішніх справ Румунії Костянтином Аржетояну (1871-1955) та міністром Буковини Доримедонтом (Дорі) Поповичем (1873-1950) $)^{23}$. Дозвіл був одержаний. Редакцію тижневика очолив доктор права, адвокат, журналіст і видавець Лев Когут (1878-1947). Газета створювалася як демократичне, національне видання, що стояло на позиціях УНР і захисту національних інтересів Великої України. Три чверті накладу повинно було поширюватися за кордоном, решта - в Україні. Редакції заборонялося втручатися у справи внутрішньої політики влади на Північній Буковині й у Східній Галичині. Коректуру і письмові матеріали переглядав сам К. Мацієвич. Із його особистого фонду на видання тижневика виділялося 10 тис. леїв, що надсилалися представнику НДМ у Чернівцях Свгену Луговому. Останній відповідав за його поширення за кордоном і доставку в Україну ${ }^{24}$. Наклад становив 5 тис. примірників і розподілявся між МЗС УНР у Тарнові, пресовим бюро, військовою секцією НДМ, представником НДМ у Чернівцях та редактором тижневика ${ }^{25}$. Із часом тираж збільшився. У червні 1921 р. лише до України було відправлено 15 тис. примірників ${ }^{26}$.

Газета почала виходити з травня 1921 р., проте після третього номера К. Мацієвич тимчасово припинив ії видання. У липні того самого року він повідомив МЗС УНР про те, що «редактор, д-р Когут, не зрозумів характеру і напрямку газети. Тому я складаю тепер ї̈ тут, в Місії і надсилаю готовий матеріал для друку в Чернівиях $і$ для випуску там газети. Велика користь нашого видання в тому, щьо вся газета в кількості 15 тис. примір- 


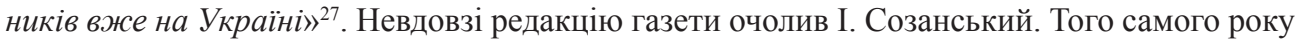
тижневик припинив своє існування і відновився 1923 р., але без участі НДМ.

Друкованим органом дипломатичного представництва був «Бюлетень Пресового Бюро НДМ УНР» в Румунії. На його сторінках висвітлювалося життя української еміграції взагалі й окремих іiї організацій та місцевих осередків (колоній) зокрема.

На початку 1920-х рр. головним своїм завданням НДМ вважала об'єднання української еміграції. Для цього, на думку К. Мацієвича, необхідно було створити Український громадський комітет. У жовтні 1921 р. голова НДМ визначив головні завдання цього комітету: піклування долею інтернованих і біженців, захист їхніх матеріальних і духовних інтересів, культурно-освітня та кооперативна діяльність, налагодження зв'язку з румунською громадськістю та поширення ідей української державності. Тоді ж розпочалася підготовча робота ${ }^{28}$. Однак Український громадський комітет, який пізніше отримав назву Громадсько-допомогового комітету, не став першою громадською організацією еміграції, що була започаткована з ініціативи та за сприяння НДМ.

У 1920 р. у Відні з ініціативи уряду УНР було створено Українське товариство (прихильників) Ліги Націй. Про необхідність відкриття його філій у країнах Свропи С. Петлюра писав К. Мацієвичу ще у жовтні 1920 p. ${ }^{29}$ А 21 вересня 1922 р. у приміщенні НДМ УНР у Бухаресті зібралась ініціативна група зі створення філії Українського товариства Ліги Націй (ФУТЛН) у Румунії. 1 жовтня там же відбулись установчі збори ФУТЛН. Було затверджено статут та обрано управу філії, до складу якої ввійшли голова та деякі члени НДМ $^{30}$.

Навесні 1923 р. керівництво НДМ продовжило організаційну діяльність на ниві об'єднання українських емігрантів, оскільки побоювалося ліквідації українського дипломатичного представництва в Румунії. В одному з листів до С. Петлюри голова НДМ обгрунтовував це так: «На випадок все ж таки зачинення Місії, ми зараз переводимо велику організаційну роботу для того, аби залість неї залишити нові якісь иеентри і установи, щзо не допустили б розпорошення нашої емігращії» ${ }^{31}$.

Другою громадською організацією української еміграції в Румунії, що виникла за сприяння НДМ і ФУТЛН, був Союз українських жінок-емігранток. Він розпочав свою діяльність у березні 1923 р. Серед його керівників - дружини членів НДМ Ніна Трепке, Антоніна Івашина.

У квітні 1923 р. у Бухаресті створене Українське співоче товариство «Дума» на чолі 3 композитором Миколою Бойченком (1896-1946). Під час його відкриття НДМ надала матеріальну допомогу у розмірі 500 леїв $^{32}$.

3 метою поліпшення економічного становища українських емігрантів було засноване перше в Румунії Українське ощадно-позичкове товариство «Згода». Установчі збори кооперативу відбулися 6 травня 1923 р. у приміщенні НДМ. Головою Наглядової ради товариства обрали відомого в Росії й Україні кооператора та громадського агронома К. Мацієвича. Управа кооперативу знаходилася у приміщенні $\mathrm{HДM}^{33}$. Про важливість справи створення кооперативів К. Мацієвич писав С. Петлюрі у листі від 2 травня 1923 р.: «Особливу Вашу увагу звертаю на наш почин організачії Економічного Товариства. Аби такі організації утворилися скрізь: в Польщі, Чехії, Німеччині, Франиії, Австрії та інших країнах, а потім об' 'єдналися в якусь союзну організацію, то з изього б вийшло досить поважне діло» ${ }^{34}$.

Дипломатична місія підтримувала українську пресу в інших країнах. У липні 1923 р. НДМ разом із ФУТЛН виділила журналу «Сурмач» щомісячну грошову допомогу на суму 200 тис. польських марок і передплатила 25 примірників часопису «Трибуна України» Обидва журнали виходили у Польщі.

Наступним кроком в організаційному оформленні української еміграції в Румунії стало скликання 15-17 вересня 1923 р. iï Першої конференції. Одним із ініціаторів форуму виступила НДМ. Вона ж надала своє приміщення для засідань, а їі члени були обрані до президії конференції та Громадсько-допомогового комітету української еміграції в Румунії ${ }^{36}$

Однак і після припинення існування як дипломатичної установи НДМ брала участь у громадському житті еміграції в Румунії. Так, 26 травня 1926 р. у Бухаресті був створений Комітет імені С. Петлюри в Румунії. Заснували його представники всіх існуючих на той час у Румунії громадських організацій української еміграції та НДМ ${ }^{37}$. 
У Болгарії роль Посольства УНР у справі створення громадських організацій українських емігрантів була набагато меншою, ніж НДМ УНР у Румунії. За час свого існування (1918-1923) Посольство очолювали Олександр Шульгин (1889-1960), Федір Шульга та Василь Драгомирецький. Співробітниками представництва були Іоаникій Додул, Микола Лаврик, Юліан Налисник, Петро Сікора, Дмитро Шелудько, по військовому найму - Юліан Вільчинський, військовим агентом (аташе) - генерал Борис Бобровський (1868-1933) Посольство не виступило локомотивом у справі об'єднання української еміграції. У січні 1921 р. в. о. секретаря Посольства УНР в Болгарії В. Драгомирецький у доповіді до МЗС УНР аргументував це тим, що, по-перше, бракувало грошей не лише на допомогу біженцям, але й на утримання самого Посольства, яке могло підтримати співвітчизників тільки морально, тобто видати документи та безкоштовні квитки на виїзд із країни, рекомендувати на роботу, влаштувати військових на ночівлю до казарм тощо. У країні не існувало тоді жодної української організації, яка б гуртувала навколо себе емігрантів, оскільки серед них, на думку дипломата, не було на той момент ініціативних і національно свідомих українців. По-друге, дипломатичне представництво через свій офіційний статус не могло цього зробити ${ }^{39}$.

Після приїзду у березні 1921 р. до Софії голови НДМ УНР в Румунії К. Мацієвича ${ }^{40}$, який опікувався справами Посольства УНР у Болгарії, місцеве українське дипломатичне представництво здійснило низку заходів щодо надання допомоги біженцям/емігрантам та об'єднання їх у громадські організації. Допомога біженцям здійснювалася через Тимчасовий комітет Українського товариства Червоного Хреста, до складу якого входив і В. Драгомирецький. Завдяки ініціативі Тимчасового комітету місцева влада дозволила перетворити колишній військовий барак на притулок «Українська хата» для новоприбулих біженців, хворих та інвалідів. Ремонт барака українські емігранти здійснили самотужки ${ }^{41}$. Щодо створення громадських організацій, то дипломатичний агент УНР у Болгарії не виявив активності та наполегливості.

Ініціатором створення першої громадської організації в Болгарії виступив підполковник Армії УНР Василь Филонович (1894-1987). У листі до свого колишнього командира Архипа Кмети від 21 червня 1927 р. він згадував про події грудня 1920 - січня 1921 рр. так: «Коли я з групою украӥнців приїхав з Царгороду до Болгарії і побачив повну незорганізованість, подав проект утворення укр [аӥнської] організації. Цей проект п[ан] Драгомиреиький відкинув і був взагалі проти такої організації. Однак я зібрав біля 30 душ, куди увійшли i п [ан] Храпко та п[ан] Крупииький, і так заложена була перша укр [аӥнська] організація на терені Б[олгарії]»42. Більш детально про ставлення керівника Посольства УНР В. Драгомирецького до справи згуртування емігрантів йшлося у доповіді В. Филоновича військовому міністрові УНР в екзилі генералові Володимиру Сальському (1885-1940) від 17 липня 1931 р. Керівник Посольства УНР не лише не допоміг відкриттю Української громади в Софії, але й відмовляв від будь-якої ініціативи у цій справі, оскільки це, на його думку, могло викликати «гонєнія» не лише щодо українських біженців, а й Посольства, бо «руськіє заклюють». Не сприяв В. Драгомирецький і поширенню українських організацій у болгарській провінції, оскільки вважав, що «можна працювати і так під "захистом" Укр[аӥнської] легацїі» ${ }^{43}$. Згодом завдяки зусиллям В. Филоновича Українська громада була легалізована, з'явилася низка громадських організацій української еміграції ${ }^{44}$. Зусиллями підполковника та за сприяння дипломатичного агенту УНР в Болгарії й одночасно голови Тимчасового комітету Українського Червоного Хреста В. Драгомирецького в Софії відкрився притулок «Украӥнська хата» ${ }^{45} .3$ від”їздом наприкінці 1922 р. В. Филоновича до Чехословаччини дипломат перебрав на себе справу опіки над цими організаціями. Проте через зовнішні впливи з боку російських емігрантів і більшовицьких агентів та внутрішні чвари між українськими емігрантами, в яких брав участь і В. Драгомирецький, легальні українські громадські організації в Болгарії невдовзі були заборонені ${ }^{46}$. А 1 травня 1923 p. і Посольство УНР в Болгарії припинило своє існування. Деякі його функції, крім видачі українських паспортів, перебрав на себе Українсько-болгарський комітет ${ }^{47}$.

Оскільки у Королівстві сербів, хорватів і словенців місцева влада не визнавала УНР і ЗУНР й українських біженців як окрему категорію емігрантів, то й українські дипломатичні представництва, які там фактично діяли невеликий проміжок часу, але не мали офіційного статусу, теж не визнавалися. Відповідно їх діяльність мала обмежений 
характер у справі створення мережі громадських організацій еміграції. Відкрите у січні 1921 р. Генеральне консульство УНР у Загребі на чолі з почесним консулом Стефаном Лукіяновичем започаткувало Українське пресове бюро під керівництвом Михайла Петріва (М. Гардовий), Український еміграційний комітет та «Академічну громаду» (Студентське товариство) у Загребі. Основний тягар організаційної роботи та фінансування цих організацій взяв на себе С. Лукіянович. Проте через недостатність фінансування консульства 3 боку Уряду УНР в еміграції та переведення його діяльності на громадські засади із часом пресове бюро і комітет припинили своє існування, а студентська організація продовжувала діяти до середини 1920-х рр. Почесний консул не лише надав «Академічній громадi» окрему кімнату в своєму приміщенні, але й «дбав про ї̈ господарський та просвітний розвиток» ${ }^{48}$

Отже, найбільшу активність у справі створення громадських організацій української еміграції у балканських країнах виявила Надзвичайна дипломатична місія УНР у Румунії. Вона не лише ініціювала створення цих організацій, а й фактично очолила їх. Голова та члени НДМ увійшли до складу керівних органів громадських організацій еміграції. Менш активним було Посольство УНР у Болгарії. У цій країні ініціативу в справі об'єднання українців у громадські організації виявив підполковник Армії УНР В. Филонович. У КСХС через нетривалий період існування і напівофіційний статус Генеральне консульство УНР не в змозі було виступити ініціатором створення українських громадських організацій.

${ }^{1}$ Павленко В. Дипломатична місія Української Народної Республіки в Болгарії (1918-1920рр.) // Український історичний журнал. - К., 1992. - № 12. - С. 18-31; Вішка О. Українські дипломатичні, військові та економічні представництва у Варшаві в 1919-1923 рр.) // Україна дипломатична - 2007: Наук. щорічник. - Вип. 8. - К., 2007. - С. 162-175; Власенко В. Надзвичайна дипломатична місія УНР у Румунії - організатор громадсько-політичного життя української еміграції // Сумська старовина. - 2008. - № 25. - С. 76-84; Його ж. Документи і матеріали Надзвичайної дипломатичної місії УНР в Румунії (1919-1923 рр.) // Пам’ятки: археографічний щорічник. - Т. 8. - К., 2008. - С. 129-160; Саган $Г$. Місце «української ідеї» у становленні дипломатичної служби УНР у Королівстві сербів, хорватів і словенців // Українознавчий альманах. - К., 2010. - № 2. - С. 52-54; Власенко В., Сапсай O. Склад і структура Надзвичайної дипломатичної місії УНР в Румунії // Суспільно-політичні процеси на українських землях: історія, проблеми, перспективи: зб. матер. III Всеукр. наук.-практ. конф., м. Суми, 17 квітня 2015 р.: у 2-х ч. - Суми: СумДУ, 2015. - Ч. 1. - С. 56-64.

${ }^{2}$ Трощинський В. П. Міжвоєнна українська еміграція в Свропі як історичне і соціально-політичне явище. - К.: Інтел, 1994. - 259 с.

${ }^{3}$ Срібняк I. B. Українці на чужині. Полонені та інтерновані вояки-українці в країнах Центральної та Південно-Східної Європи: становище, організація, культурно-просвітницька діяльність (19191924 рр.). - К.: [б. в.], 2000. - 280 с.; Власенко В. До історії міжвоєнної української політичної еміграції на Балканах // Пам’ятки: археографічний щорічник. - Т. 12. - К., 2011. - С. 124-145; Його ж. До історії української еміграції у Південно-Східній Свропі (Український Червоний Хрест на Балканах) // Пам'ятки: археографічний щорічник. - Т. 14. - К., 2013. - С. 75-92.

${ }_{5}^{4}$ Павленко В. Українсько-болгарські взаємини 1918-1939 рр. - К., 1995. - 224 с.

${ }^{5}$ Козлитин В. Д. Русская и украинская эмиграция в Югославии (1919-1945 гг.). - Харьков: «РА», 1996. - 476 с.; Його ж. Українські громадські організації в Югославії (20-30-ті рр. ХХ ст.) // Українці Хорватії. Матеріали і документи = Ukrajinci Hrvatskej. Materiali i dokumenti. - Кн. 1. - Загреб: Grafika, 2002. - C. 21-37.

${ }^{6}$ Срібняк I. Обеззброєна, але нескорена: Інтернована Армія УНР у таборах Польщі й Румунії (1921-1924 рр.). - К.: Вид-во ім. Олени Теліги, 1997. - 128 с.; Павленко М. Українські військовополонені й інтерновані у таборах Польщі, Чехословаччини та Румунії: ставлення влади і умови перебування (1919-1924 рр.). - К., 1999. - 352 с.

7 Доманииький В. Кость Мацієвич (Замісць вінка на могилу). - К., 1943; Власенко В. Штрихи до портрета Костя Мацієвича // Сумська старовина. - 1997. - № 1. - С. 25-30; Матвієнко В., Головченко B. Історія української дипломатії XX століття у постатях. - К., 2001. - С. 78-82; Власенко В. Агроном і дипломат. Штрихи до біографії Костя Мацієвича // Політика і час. - К., 2002. - № 10. - С. 78-86; Його ж. Кость Мацієвич: штрихи до портрета // Вісник Львівської комерційної академії. Сер.: гуманітарні науки. - Вип. 4. - Львів, 2002. - С. 67-78; Табачник Д. Українська дипломатія: нариси історії (1917-1990 рр.). - К., 2006. - С. 278-297; Спик Л. I. К. А. Мацієвич - науковець, дипломат, громадсько-політичний діяч // Український історичний журнал. - 2007. - № 1. - С. 125-135; Власенко В. Візит Костя Мацієвича до Болгарії навесні 1921 р. // Суспільно-політичні процеси на українських землях: історія, проблеми, перспективи: зб. матер. III Всеукр. наук.-практ. конф., м. Суми, 17 квітня 2015 р.: у 2-х ч. - Суми: СумДУ, 2015. - Ч. 1. - С. 3-7 та інші. 
${ }^{8}$ Власенко В. Перша хвиля міжвоєнної української політичної еміграції до Б олгарії // Българска украинистика. - 2013. - № 3. - С. 172-184; Його ж. Друга хвиля міжвоєнної української політичної еміграції у Південно-Східній Європі // Сумська старовина. - 2013. - № XL. - С. 22-35; Eго же. Вторая волна межвоенной украинской политической эмиграции в Румынии (зима-весна 1920 г.) // Русин. - 2014. - № 2 (36). - С. 270-284; Его же. Третья волна межвоенной украинской политической эмиграции в Румынии // Русин. - 2014. - № 4 (38). - С. 99-114; Его же. Формирование украинской политической эмиграции в Румынии в межвоенный период (первая волна) // Русин. - 2014. - № 1 (35). - С. 105-120; Його ж. Формування міжвоєнної української політичної еміграції в Югославії (перша хвиля) // Наукові праці історичного факультету Запорізького національного університету. 2014. - Вип. XXXIX. - С. 85-91; Його ж. Третя хвиля міжвоєнної української еміграції до Болгарії // Дриновський збірник. - Харків-Софія, 2015. - Т. VIII. - С. 184-195; Його ж. Третя хвиля міжвоєнної української еміграції до Югославії // Русинистични студиї = Ruthenian studies: електронско издање / [главни редактор Юлиян Тамаш]. - Нови Сад: Универзитет у Новом Саду, Филозофски факултет, 2015. - С. 103-132; Його ж. Евакуація російської армії генерала П. Врангеля з Криму: український контекст // Ucraina magna. - K., 2016. - Vol. 1: Українська політична еміграція у XX столітті: досвід культурно-спільнотного себепредставлення і самоутвердження у Західному світі. - С. 208-221.

9 Власенко B. Н. Натурализация украинской эмиграции в Болгарии в межвоенный период // Анамнеза [историческо списание] / Софийски ун-т «Св. Климент Охридски». - Год. Х. - София, 2015. - Кн. 1. - С. 18-33.

${ }^{10}$ Власенко В. М. Соціальна структура міжвоєнної української політичної еміграції в Румунії // Сумська старовина. - 2015. - № XLVI. - C. 43-53.

11 Власенко $B$. Правове становище міжвоєнної української еміграції в Румунії (міжнародний аспект) // Сумська старовина. - 2014. - № XLV. - C. 29-36.

${ }^{12}$ Власенко В. Консервативно-гетьманське середовище міжвоєнної української еміграції в країнах Південно-Східної Свропи (1918-1939) // Сумський історико-архівний журнал. - 2015. - № XXV. - С. 56-67; Власенко В., Гузун В. Національно-демократичне середовище міжвоєнної української еміграції в країнах Південно-Східної Свропи // Сумська старовина. - 2016. - № XLVIII. - C. 25-49.

${ }^{13}$ Козлітін B. Українські громадські організації в Югославії (20-30-ті рр. XX ст.) // Українці Хорватії. Матеріали і документи = Ukrajinci Hrvatskej. Materiali i dokumenti. - Кн. 1. - Загреб: Grafika, 2002. - С. 21-37; Власенко B. Українська громада у Белграді у міжвоєнний період (за матеріалами паризького «Тризуба») // Київська старовина. - 2011. - № 1. - С. 123-136; Його ж. Українська громада у Великому Бечкереку (Югославія) у міжвоєнний період // Київська старовина. - 2011. - № 3 . - С. 41-48; Його ж. Філія Українського національного козацького товариства у Болгарії (1923-1936) за матеріалами болгарського і чеського архівів // Дриновський збірник. - Харків-Софія, 2012. T. V. - C. 428-443; Його ж. Українське культурне об’єднання в Болгарії // Дриновський збірник. Харків-Софія, 2014. - T. VI. - С. 87-97 та інші.

${ }^{14}$ Центральний державний архів вищих органів влади та управління України (далі - ЦДАВО), ф. 3696 , оп. 1, спр. 69, арк. 9.

${ }^{15}$ ЦДАВО, ф. 3696, оп. 2, спр. 308, арк. 87

${ }^{16}$ Порохівський Г. Українська військова еміграція в Румунії // Табор. - Варшава, 1930. - Кн. 13. С. 61; Життя інтернованих в Румунії // Воля. - Відень, 1921. - Т. IV. - Ч. 9-10. - С. 391-392.

${ }^{17}$ ЦДАВО, ф. 3696, оп. 2, спр. 308, арк. 155зв; спр. 489, арк. 1253 в.

${ }^{18}$ Там само, ф. 3696, оп. 1, спр. 162, арк. 25.

19 Там само, ф. 3696, оп. 2, спр. 215, арк. 272-272зв.

${ }^{20}$ Там само, ф. 3696, оп. 1, спр. 161, арк. 13; оп. 2, спр. 259, арк. 19.

${ }^{21}$ Там само, ф. 2471, оп. 1, спр. 1, арк. 32-32зв; Власенко В. Документи і матеріали Надзвичайної дипломатичної місії УНР в Румунії (1919-1923 рр.). - С. 135-136.

${ }^{22}$ ЦДАВО, ф. 3696, оп. 2, спр. 308, арк. 48.

${ }^{23}$ Там само, ф. 3696, оп. 2, спр. 446, арк. 123в-13.

${ }^{24}$ Там само, ф. 3696, оп. 2, спр. 354, арк. 54.

${ }^{25}$ Там само, ф. 3696, оп. 1, спр. 161, арк. 17.

${ }^{26}$ Там само, ф. 3696 , оп. 2, спр. 308 , арк. 156; спр. 354, арк. 71.

${ }^{27}$ Там само, ф. 3696, оп. 2, спр. 354, арк. 71.

${ }^{28}$ Там само, ф. 3696, оп. 2, спр. 259, арк. 93-93зв.

${ }^{29}$ Вибрані листи С. В. Петлюри до К. А. Мацієвича // Пам’ять століть. - К., 2001. - № 4. - С. 29.

${ }^{30}$ ЦДАВО, ф. 4465, оп. 1, спр. 9, арк. 126-127. Більш детально про Філію УТЛН в Румунії див.: Власенко В. Кость Мацієвич на чолі Філії Українського товариства Ліги Націй у Бухаресті (19221925) // Український вимір: Зб. матеріалів міжнар. наук. конф. - Вип. 6. - Ніжин, 2007. - С. 82-85; Його ж. Філія Українського товариства Ліги Націй у Бухаресті: перші кроки // Література та культура Полісся: Збірник. - Вип. 38: Регіональна історія та культура в сучасних дослідженнях. - Ніжин: [б. в.], 2007. - С. 160-170.

${ }^{31}$ ЦДАВО, ф. 3696, оп. 2, спр. 7, арк. 298; Листи Костя Мацієвича до Симона Петлюри (19201923 рр.) / Упоряд., вступ. стаття та коментарі В. Власенка. - Суми: ФОП Наталуха А. С., 2009. - С. 66. 
${ }^{32}$ ЦДАВО, ф. 4465, оп. 1, спр. 157, арк. 16.

${ }_{33}^{33}$ Павленко М. Українські військовополонені й інтерновані у таборах Польщі, Чехословаччини та Румунії: ставлення влади і умови перебування (1919-1924 рр.). - С. 283.

${ }^{34}$ ЦДАВО, ф. 3696, оп. 2, спр. 7, арк. 302зв; Листи Костя Мацієвича до Симона Петлюри (19201923 рр.). - С. 76. Більш детально про кооперативний досвід української еміграції в Румунії див.: Власенко В. Кооперативний досвід міжвоєнної української політичної еміграції в Румунії // Український селянин. - Черкаси, 2010. - Вип. 10. - С. 203-206.

${ }_{35}^{35}$ ЦАВО, ф. 3696, оп. 2, спр. 7, арк. 306зв; Листи Костя Мацієвича до Симона Петлюри (19201923 pp.). - С. 84.

36 Детальніше про Громадсько-допомоговий комітет у Румунії див.: Власенко В. Перша конференція української еміграції у Румунії (до 85-річчя 3 дня заснування Громадсько-допомогового комітету української еміграції у Румунії) // Українознавство - 2008. Календар-щорічник. - К.: Укр. центр духовн. культури, 2007. - С. 172-178; Його ж. Самооподаткування міжвоєнної української політичної еміграції у Румунії // Наукові записки Національного університету «Острозька академія»: Історичні науки. - Вип. 15. - Острог, 2010. - С. 99-109; Його ж. Третя конференція міжвоєнної української еміграції в Румунії (до 85-річчя від дня проведення) // Студії з архівної справи та документознавства. - К., 2010. - Т. 18. - С. 170-175; Його ж. Громадсько-допомоговий комітет української еміграції в Румунії крізь призму ії конференції // Особистість, суспільство, держава: проблеми минулого і сьогодення: матер. II Міжнар. наук.-практ. конф.: у 2 ч. (Суми, 18 квітня 2016 р.). - Суми: СумДУ, 2016. - Ч. 1. - С. 3-15.

${ }^{37}$ ЦДАВО, ф. 4465, оп. 1, спр. 1087, арк. 18.

${ }^{38}$ Налисник Ю. Перше посольство Української Держави в Болгарії (спогад 3-перед 20-ти років) // Історичний календар-альманах «Червоної калини» на 1939 рік. - Львів, 1938. - С. 164-168; Історія української дипломатії: перші кроки на міжнародній арені (1917-1924рр.): Документи і матеріали. К.: Вид-во гуманіт. л-ри, 2010. - С. 206-207.

${ }^{39}$ ЦДАВО, ф. 3696, оп. 2, спр. 308, арк. 68-69.

${ }^{40}$ Більш детально про візит К. Мацієвича до Болгарії див.: Власенко В. М. Візит Костя Мацієвича до Болгарії навесні 1921 р. // Суспільно-політичні процеси на українських землях: історія, проблеми, перспективи: збірник матеріалів III Всеукр. наук.-практ. конф., м. Суми, 17 квітня 2015 р.: у 2-х ч. Суми: СумДУ, 2015. - Ч. 1. - С. 3-7.

${ }^{41}$ ЦДАВО, ф. 3696, оп. 2, спр. 308, арк. 56зв-57.

${ }^{42}$ Центральний державний архів громадських об’єднань України (далі - ЦДАГО), ф. 269, оп. 2 , спр. 261, арк. 41 .

${ }^{43}$ ЦДАГО, ф. 269, оп. 2, спр. 277, арк. 97; Власенко В. До історії міжвоєнної української політичної еміграції на Балканах. - С. 130-131.

${ }^{44}$ Про створення Української громади в Болгарії див.: Власенко В. До громадсько-політичної діяльності Василя Филоновича у Болгарії у 1921-1922 рр. // Київська старовина. - К., 2010. - № 6. С. 97-115; Його ж. Українська громада в Болгарії (за матеріалами паризького тижневика «Тризуб») // Сумська старовина. - 2011. - № 35. - С. 14-27.

${ }_{45}$ Хвиля В. Болгарія // Нова Україна. - Прага, 1923. - Ч. 6. - С. 174; Централен държавен архив на Република България, ф. 1717К, оп. 1, а.е. 373, л. 1, 2гр.

${ }^{46}$ ЦДАГО, ф. 269, оп. 2, спр. 277, арк. 98-98зв; Власенко В. До історії міжвоєнної української політичної еміграції на Балканах. - С. 132.

${ }^{47}$ ЦДАГО, ф. 269, оп. 2, спр. 267, арк. 21.

${ }^{48}$ Петрів М. Українці в Югославії // Літопис політики, письменства і мистецтва. - Берлін, 1924. - Кн. 1. - Зшиток 12 (22 березня). - С. 189. 